\title{
Performance Evaluation of Water Harvesting Catchments
}

G.W. FRASIER, K.R. COOLEY, AND J.R. GRIGGS

\section{Abstract}

The runoff efficiencies of 14 operational water harvesting catchments were estimated using a small portable sprinkler. The sprinkler method was verified using actual rainfall-runoff data from test plots of various water harvesting treatments at the Granite Reef Test Site. Sprinkler results showed that membranetype treatments yielded $90-100 \%$ runoff. The runoff from properly installed wax-type treatments averaged over $80 \%$. The sprinkler method permitted evaluation of catchment runoff efficiencies without resorting to the time and effort required for large fieldinstrumentation projects.

The performance of a water harvesting system as a water source is directly related to the relative impermeability of the catchment apron. To determine the quantity of water that can be collected from a given rainfall, the runoff efficiency of the catchment surface must be known. A common practice is to compute the water yield from field catchments based on average runoff results obtained from similarly treated small instrumented plots. Membrane treatments of sheet metal, artificial rubber, or asphalt fiberglass are commonly assumed to yield 90 to $100 \%$ of runoff. Water repellents, waxes, soil dispersants, and gravel-covered sheeting treatments have runoff efficiencies somewhat less that $90 \%$ (Frasier 1975). Field catchments, installed under less-than-ideal conditions, may have rough or irregular surfaces which can retain or trap water. On large catchments, nonuniform application or variations in soil texture can leave areas inadequately water-proofed. These and other problems can reduce the runoff efficiency of an operational water harvesting system. A small portable sprinkler was used to estimate the runoff efficiencies of various catchment treatments on 14 operational water harvesting systems.

\section{Procedure}

The sprinkler system used in the studies is shown in Figure 1. Water was sprayed downward from a height of $152 \mathrm{~cm}$ onto a 1 -meter square test area from a single, low pressure, wide angle, fine drop size, full square spray nozzle. The test area was located in the center of the spray

The authors are research hydraulic engineer, Southwest Rangeland Watershed Researcl Center, Tucson, Arizona; hydrologist, U.S. Water Conservation Laboratory, Phoenix Arizona; and physical science technician, Southwest Rangeland Watershed Research Center, Tucson, Arizona.

Gary Frasier and John Griggs were formerly located at the U.S. Water Conservation Laboratory at Phoenix, Arizona.

This report is a contribution of the Soil, Water, and Air Sciences Program, Agricultural Research Science and Education Administration, U.S. Department of Agriculture. The paper was presented in part at the 30th Annual Meeting, Society of Range Management, Portland, Oregon, 14-18 Feb., 1977, under the title "Performance Evaluation of Water Harvesting Systems,"' by G.W. Frasier, D.H. Fink, and K.R. Cooley.

This work was partially funded by the Bureau of Land Management, U.S. Dep. Interior under Reimburseable Agreement ARS No. 12-14-5001-64311, whose assistance is gratefully acknowledged. The authors also thank Juan Martinez for his assistance in obtaining the runoff results at the Granite Reef Test Site and operation of the plot sprinkler. Manuscript received November 10, 1978. pattern and defined by a metal shield sealed to the soil surface by a foam rubber cushion on top of a layer of bentonite clay. The runoff water from the soil was trapped at the lower side of these test area and collected by a small vacuum line for measurement in a graduate plastic chamber. Wind disturbance of the spray was minimized by a curtain fastened to the framework. Water sprayed outside the 1-square meter test area was collected in a channel around the metal shield and conveyed away from the test area. The spray application rate was set prior to testing by placing a metal pan over the test area and adjusting the water pressure at the nozzle until a constant spray rate of 45 to 50 $\mathrm{mm} / \mathrm{hr}$ was achieved. Without shutting off the spray, the pan was removed, and the water was then sprayed directly onto the catchment surface within the test area for 10 to 15 minutes. The sprinkler was then moved to a new location on the catchment surface and the procedure repeated. Two to three sites were usually evaluated on each catchment.

The accumulative runoff from each test was recorded and plotted vs. the accumulative water applied (Fig. 2). The best fit straight line from least square regression analysis was fitted for all points after runoff had started. The $X$-axis intercept represented the threshold rainfall or the amount of water applied before runoff started. The slope of the line represented the runoff efficiency of the treatment after runoff started. The sprinkler method was compared with actual rainfall results obtained from 11 different types of water harvesting membranes and soil treatments on field-sized plots at the Granite Reef Test Site, located approximately $25 \mathrm{~km}$ northeast of Mesa, Ariz. The treatments are described in Table 1. Precipitation runoff from each plot was collected in an underground tank and measured after each storm event by pumping the water through precalibrated water meters. Precipitation was measured with a network of rain gages. For each plot, the actual rainfall threshold and runoff efficiency after threshold was determined by standard linear regression analysis of rainfall-runoff data from individual storm events, but omitting storm events with zero runoff (Fink and Frasier 1977).

\section{Results and Discussion}

\section{Granite Reef Test Site}

Table 2 shows the sprinkler-runoff and the rainfall-runoff results for the 11 plots at the Granite Reef Test Site. Linear regression analysis showed that the sprinkler treatments overestimated the runoff efficiencies by $8 \%$ on the treatments with low runoff efficiencies $(50-70 \%)$, but by only $2 \%$ on the treatments with good runoff efficiency $(90-100 \%)\left(r^{2}=.8\right)$. This may have resulted from the relatively high sprinkling rate as compared with average rainfall intensities of actual storm events. The sprinkler overestimated the threshold rainfall by 0.8 $\mathrm{mm}$ on all of the treatments $\left(r^{2}=.86\right)$. The sprinkler evaluation results for the silicone treatments showed large variations in the runoff efficiencies and threshold rainfalls within the catchment areas. Myers and Frasier (1969) showed that this could have resulted from non-uniform treatment application, soil erosion, 


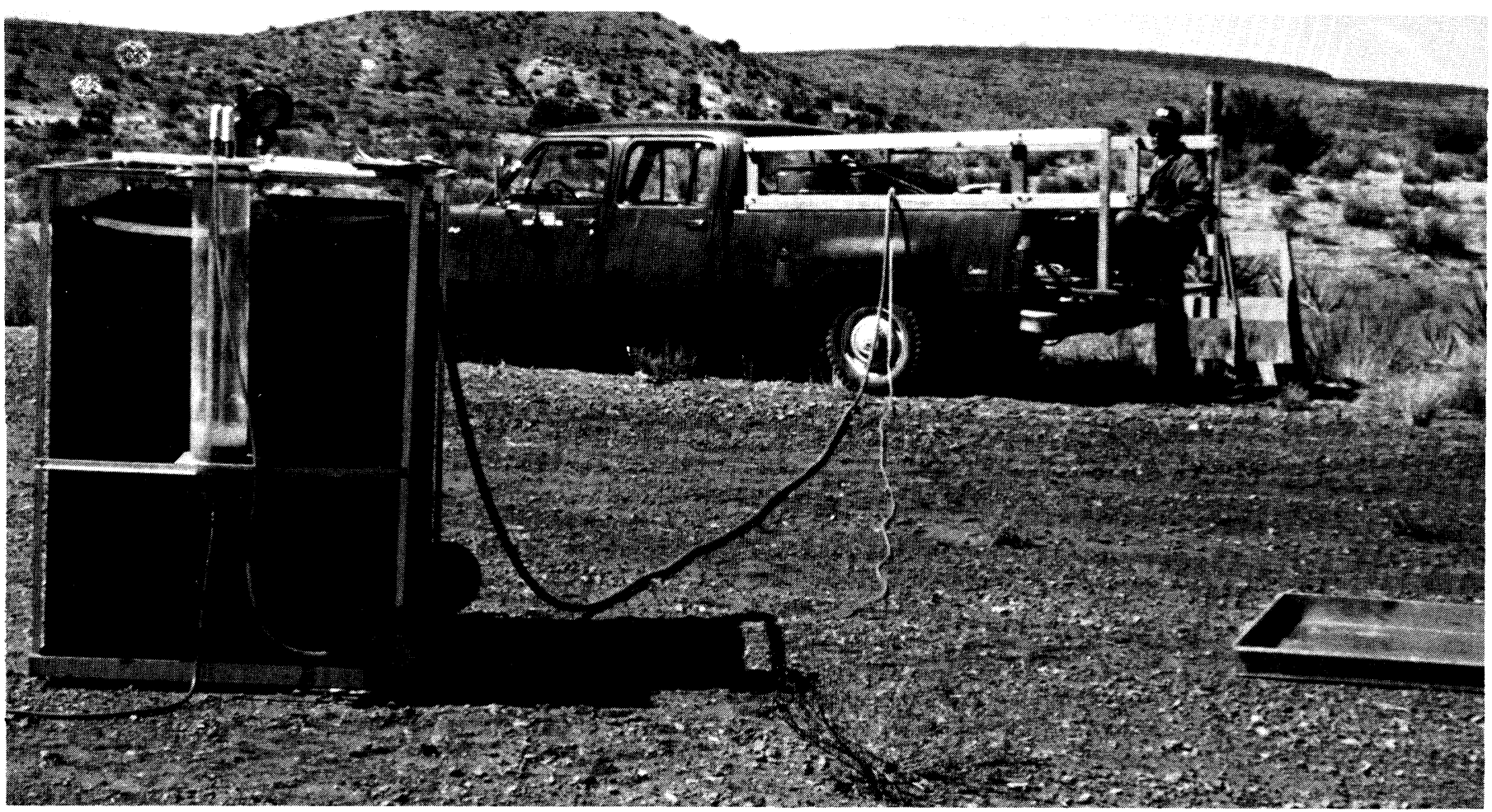

Fig. 1. Portable sprinkler for determining runoff efficiencies

and treatment deterioration.

Based on these studies, we concluded that the sprinkler method could be used to estimate the performance of membrane and some chemical soil treatments.

\section{Operational Water Harvesting Catchments}

Table 3 summarizes results of sprinkler tests on 14 operational water harvesting catchments in Arizona with various surface treatments. The first five catchments have membrane-type treatments. The gravel-covered polyethylene catchment (Boggs Ridge) had the highest threshold rainfall (4.4 $\mathrm{mm}$ ) plus relatively low runoff efficiency $(57 \%)$. Inspection of the plastic sheeting under the gravel revealed numerous small holes, probably caused during installation which contributed to the poor runoff performance. The resin fiberglass, asphaltfiberglass, and butyl-rubber catchments each had good runoff efficiencies and low threshold water retention.

The remaining nine catchments were water repellent treatments of paraffin wax, installed 2 months to 3 years prior to testing. The Slope catchment has been tested five times since installation. The average threshold rainfalls were essentially the same for all tests. The lower runoff efficiencies measured in the spring as compared to the fall tests indicated climate and/or soil

Table 1. Treatment description of plots at the Granite Reef Test Site.

\begin{tabular}{|c|c|c|c|c|c|}
\hline Treatment & $\begin{array}{l}\text { Catchment area } \\
\qquad\left(\mathrm{m}^{2}\right)\end{array}$ & Shape & $\begin{array}{l}\text { Slope } \\
(\%)\end{array}$ & $\begin{array}{l}\text { Treatment age } \\
\text { (Years) }\end{array}$ & Treatment description \\
\hline $\begin{array}{l}\text { Chlorinated } \\
\text { polyethylene }\end{array}$ & 200 & Square & 5 & 8.5 & 30 mil chlorinated polyethylene bonded to soil with asphalt emulsion \\
\hline $\begin{array}{l}\text { Asphalt- } \\
\text { polypropylene }\end{array}$ & 200 & Square & 5 & 0.2 & $\begin{array}{l}\text { Polypropylene matting and anionic asphalt emulsion (SS-2) }(1.5 \mathrm{~kg} \\
\left.\text { asphalt } / \mathrm{m}^{2}\right) \text { sealed with clay asphalt emulsion }\left(1.4 \mathrm{~kg} \text { asphalt } / \mathrm{m}^{2}\right)\end{array}$ \\
\hline $\begin{array}{l}\text { Asphalt } \\
\text { fiberglass }\end{array}$ & 180 & Rectangular & 5 & 9.3 & $\begin{array}{l}\text { Chopped fiberglass matting and cationic asphalt emulsion (RSK) } \\
\left(1.5 \mathrm{~kg} \text { asphalt } / \mathrm{m}^{2}\right) \text { sealed with clay asphalt emulsion }(1.4 \mathrm{~kg} \\
\left.\text { asphalt } / \mathrm{m}^{2}\right)\end{array}$ \\
\hline Wax & 197 & Rectangular "V" & 10 & 4.2 & Refined paraffin wax, $55 \mathrm{C}$ AMP $\left(0.7 \mathrm{~kg} / \mathrm{m}^{2}\right)$ \\
\hline Aluminum foil & 200 & Square & 5 & 9.3 & $\begin{array}{l}1 \mathrm{mil} \text { aluminum foil bonded to soil with RSK asphalt emulsion } \\
\left(0.7 \mathrm{~kg} \text { asphalt } / \mathrm{m}^{2}\right)\end{array}$ \\
\hline Sprayed asphalt & 200 & Square & 5 & 13.6 & $\begin{array}{l}\text { Basecoat of rapid cure asphalt }(\mathrm{RC})\left(1.5 \mathrm{~kg} \text { asphalt } / \mathrm{m}^{2}\right) \text {. Sealcoat } \\
\mathrm{SS}-2 \text { asphalt emulsion }\left(2.0 \mathrm{~kg} \text { asphalt } / \mathrm{m}^{2}\right)\end{array}$ \\
\hline Concrete & 112 & Rectangular & 4 & 8.2 & Concrete slab $15 \mathrm{~cm}$ thick \\
\hline Gravelled roof & 180 & Rectangular & 5 & 9.3 & Standard rag felt-rock roofing \\
\hline Silicone (1) & 200 & Square & 5 & 1.5 & Silicone water repellent $\left(0.057 \mathrm{~kg} / \mathrm{m}^{2}\right)$ \\
\hline Silicone (2) & 195 & Rectangular "V" & 10 & 2.1 & Silicone water repellent $\left(0.030 \mathrm{~kg} / \mathrm{m}^{2}\right)$ \\
\hline Silicone (3) & 180 & Rectangular & 5 & 6.1 & $\begin{array}{l}\text { Silicone water repellent }\left(0.036 \mathrm{~kg} / \mathrm{m}^{2}\right) \text {, plus soil stabilizer }(0.024 \\
\left.\mathrm{kg} / \mathrm{m}^{2}\right)\end{array}$ \\
\hline
\end{tabular}




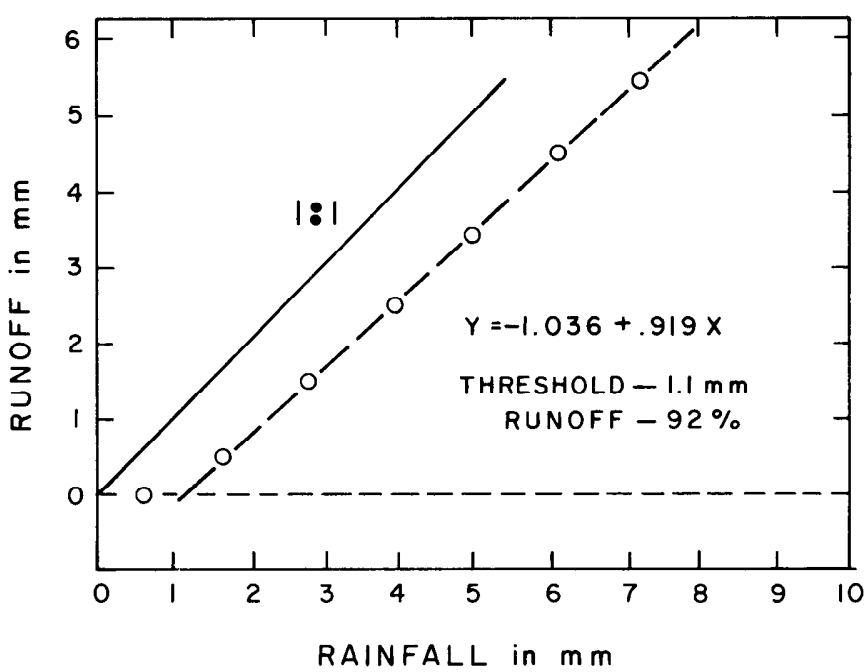

Fig. 2. Rainfall runoff relationship as determined with portable plot sprinkler.

temperature may have affected the performance of the treatments. During cooler periods, the wax may crystallize and crack, which could reduce the soil water repellency. During the summer, the soil temperature would be sufficient to remelt the wax and restore the water repellency.

Runoff efficiencies measured on the Snap Point catchment are relatively low; yet this water-harvesting system is supplying the required amount of drinking water for the livestock and wildlife using the area (Cooley et al. 1978).

The low runoff efficiency measured on the Temple catchment in August, 1976, may have been expected in retrospect. The recommended procedure for wax treatments is to construct catchments with less than $8 \%$ slope so that the velocity of the water flowing over the catchment surface is low enough to minimize possible soil erosion. This catchment had an average slope of over $10 \%$, and in some areas the slopes were approximately $20 \%$. Also, the original was application rate was less than what now is recommended for soils of this type. This catchment surface was severely damaged from an unusually intense thunderstorm in September 1976. The damaged areas were repaired and retreated with wax in July, 1977. Sprinkler tests since then indicate good runoff efficiencies (over 80\%). The catchment still has an excess slope, and can potentially be damaged by high intensity precipitation events.

Tests on the Westwind catchment in August, 1976, showed an average runoff efficiency of $88 \%$. It was believed that insufficient wax for the soil type had been applied. In July, 1977, additional wax was applied. Sprinkler tests since re-treatment have not shown a consistent increase in runoff efficiencies. Runoff averaged 90,84 , and $85 \%$ when checked in August, 1977, May, 1978, and September, 1978, respectively.

The Burnt Ridge, Toquer, and Gubler catchments were all treated in July, 1977. Sprinkler tests in August, 1977, showed average runoff efficiencies of 92 and $95 \%$ from Burnt Ridge and Toquer, respectively, but the Gubler catchment averaged only $59 \%$. Similar runoff efficiencies were measured on these three catchments in May, 1978, and September, 1978. The exact cause of the poor performance on the Gubler catchment is unknown. Some chemicals in the soil may be causing an adverse interaction with the paraffin.

The Corner catchment was hand smoothed and treated with a granulated paraffin wax spread on the soil surface in a uniform layer. The hot soil temperatures during the next 3 days were sufficient to melt the wax into the soil. Sprinkler tests on this catchment in May, 1978, showed essentially $100 \%$ runoff. The threshold rainfall was relatively high, partially a result of the rough catchment surface.

The Graham catchment had the best runoff results (100\%) of any of the field catchments treated with wax. The soil at this site is a loamy sand formed from decomposed granite. This catchment also has a southwestern exposure, which was an

Table 2. Sprinkler-runoff and rainfall-runoff efficiencies of 11 water harvesting treatments at the Granite Reef Test Site.

\begin{tabular}{|c|c|c|c|c|c|c|}
\hline \multirow[b]{2}{*}{ Treatment } & \multirow[b]{2}{*}{ Test year } & \multirow[b]{2}{*}{ No. of tests } & \multicolumn{2}{|c|}{ Sprinkler evaluation } & \multicolumn{2}{|c|}{ Precipitation efficiency } \\
\hline & & & $\begin{array}{l}\text { Threshold rainfall } \\
(\mathrm{mm})\end{array}$ & $\begin{array}{c}\text { Runoff efficiency } \\
\text { after threshold } \\
(\%)\end{array}$ & $\begin{array}{l}\text { Threshold rainfall } \\
\qquad(\mathrm{mm})^{1}\end{array}$ & $\begin{array}{l}\text { Runoff efficiency } \\
\text { after threshold } \\
(\%)^{1}\end{array}$ \\
\hline Chlorinated polyethylene & 1976 & 1 & .6 & 100 & .1 & 97 \\
\hline Asphalt-polypropylene & 1977 & 1 & 1.2 & 100 & .4 & 100 \\
\hline Asphalt- & 1976 & 1 & 1.0 & 95 & .1 & 97 \\
\hline fiberglass & 1977 & 1 & 1.0 & 96 & .1 & 95 \\
\hline \multirow[t]{2}{*}{ Wax } & 1976 & 2 & 1.2 & $\begin{array}{c}92 \\
(91-93)^{2}\end{array}$ & .2 & 88 \\
\hline & 1977 & 3 & $\begin{array}{c}1.1 \\
(0.9-1.4)^{3}\end{array}$ & $\begin{array}{c}86 \\
(79-99)\end{array}$ & .1 & 81 \\
\hline Aluminum foil & 1976 & 1 & 1.3 & 88 & .3 & 82 \\
\hline Sprayed asphalt & 1976 & 1 & 1.1 & 84 & .3 & 77 \\
\hline Concrete & 1977 & 1 & 1.1 & 75 & .9 & 75 \\
\hline Gravel-covered roofing & 1977 & 2 & $\begin{array}{c}2.8 \\
(2.6-2.9)\end{array}$ & $\begin{array}{c}77 \\
(74-80)\end{array}$ & 1.8 & 74 \\
\hline \multirow[t]{2}{*}{ Silicone (1) } & 1976 & 2 & $\begin{array}{c}2.9 \\
(1.7-1.3)\end{array}$ & $\begin{array}{c}90 \\
(81-99)\end{array}$ & 1.8 & 76 \\
\hline & 1977 & 3 & $\begin{array}{c}2.9 \\
(1.7-4.4)\end{array}$ & $\begin{array}{c}81 \\
(74-91)\end{array}$ & 2.3 & 67 \\
\hline Silicone (2) & 1977 & 3 & $\begin{array}{c}1.4 \\
(1.1-1.9)\end{array}$ & $\begin{array}{c}79 \\
(66-91)\end{array}$ & 1.1 & 71 \\
\hline Silicone (3) & 1977 & 3 & $\begin{array}{c}1.6 \\
(1.1-2.0)\end{array}$ & $\begin{array}{c}72 \\
(66-77)\end{array}$ & 1.8 & 66 \\
\hline
\end{tabular}

${ }^{1}$ Determined by linear regresson as described by Fink and Frasier, 1977. Does not include storms with no runoff.

${ }^{2}$ Range of runoff efficiency.

Range of threshold rainfall. 
Table 3. Threshold runoff and runoff efficiency after threshold as determined by sprinkler testing on 14 operational water harvesting catchments.

\begin{tabular}{|c|c|c|c|c|c|c|c|c|}
\hline \multirow[b]{2}{*}{ Catchment name } & \multirow[b]{2}{*}{ Treatment } & \multicolumn{2}{|c|}{ Date } & \multicolumn{2}{|c|}{ Threshold rainfall } & \multicolumn{2}{|c|}{ Runoff efficiency } & \multirow[b]{2}{*}{$\begin{array}{c}\text { Range } \\
(\%)\end{array}$} \\
\hline & & Installation & test & No. of tests & $\begin{array}{c}\text { Avg } \\
(\mathrm{mm})\end{array}$ & $\begin{array}{l}\text { Range } \\
(\mathrm{mm})\end{array}$ & $\begin{array}{l}\text { Avg } \\
(\%)\end{array}$ & \\
\hline Boggs Ridge & Gravel-covered polyethylene & 70 & Apr. 76 & 2 & 4.4 & $(4.2-4.6)$ & 57 & $(44-70)$ \\
\hline Van Gusic & Asphalt-fiberglass & Oct. 70 & Apr. 76 & 3 & 0.6 & $(0.5-0.8)$ & 96 & $(92-100)$ \\
\hline Montijo & Asphalt-fiberglass & Aug. 71 & Apr. 76 & 4 & 0.7 & $(0.4-0.8)$ & 94 & $(88-100)$ \\
\hline Cowhide & Resin-fiberglass & 67 & May 76 & 1 & 0.5 & - & 97 & - \\
\hline Seegmuller & Butyl rubber sheeting & 1 & Aug. 76 & 1 & 1.3 & - & 100 & - \\
\hline \multirow[t]{5}{*}{ Slope } & Paraffin wax $\left(0.9 \mathrm{~kg} / \mathrm{m}^{2}\right)$ & Sept. 74 & May 76 & 3 & 0.9 & $(0.9-1.0)$ & 78 & $(61-91)$ \\
\hline & & & Aug. 76 & 3 & 1.4 & $(1.2-1.6)$ & 96 & $(93-100)$ \\
\hline & & & Aug. 77 & 3 & 1.2 & $(0.9-1.6)$ & 84 & $(69-84)$ \\
\hline & & & May 78 & 3 & 1.0 & $(0.6-1.2)$ & 79 & $(73-87)$ \\
\hline & & & Sep 78 & 3 & 1.6 & $(1.4-1.8)$ & 96 & $(93-100)$ \\
\hline \multirow[t]{2}{*}{ Snap Point } & Paraffin wax $\left(0.9 \mathrm{~kg} / \mathrm{m}^{2}\right)$ & Sept. 74 & May 76 & 3 & 1.1 & $(0.8-1.5)$ & 67 & $(57-79)$ \\
\hline & & & Aug. 77 & 3 & 1.0 & $(1.0-1.1)$ & 70 & $(48-88)$ \\
\hline \multirow{4}{*}{ Westwind } & Paraffin wax $\left(0.9 \mathrm{~kg} / \mathrm{m}^{2}\right)$ & June 76 & Aug. 76 & 3 & 1.1 & $(0.8-1.6)$ & 88 & $(74-99)$ \\
\hline & Additional wax $\left(0.9 \mathrm{~kg} / \mathrm{m}^{2}\right)$ & July 77 & Aug. 77 & 3 & 1.3 & $(1.3-1.3)$ & 90 & $(83-96)$ \\
\hline & & & May 78 & 3 & 1.1 & $(0.9-1.6)$ & 84 & $(84-85)$ \\
\hline & & & Sept. 78 & 3 & 2.2 & $(1.8-2.7)$ & 88 & $(76-94)$ \\
\hline \multirow[t]{3}{*}{ Temple } & Paraffin wax $\left(0.9 \mathrm{~kg} / \mathrm{m}^{2}\right)$ & & Aug. 77 & 2 & 1.3 & $(1: 3-1.3)$ & 81 & $(65-90)$ \\
\hline & Re-treated $\left(1.5 \mathrm{~kg} / \mathrm{m}^{2}\right)$ & & May 78 & 3 & 1.1 & $(0.8-1.4)$ & 94 & $(90-100)$ \\
\hline & & & Sept. 78 & 3 & 1.9 & $(1.7-2.1)$ & 87 & $(82-93)$ \\
\hline \multirow[t]{3}{*}{ Burnt Ridge } & Paraffin wax $\left(1.5 \mathrm{~kg} / \mathrm{m}^{2}\right)$ & July 77 & Aug. 77 & 3 & 1.6 & $(1.2-2.1)$ & 92 & $(81-100)$ \\
\hline & & & May 78 & 3 & 1.3 & $(1.1-1.4)$ & 84 & $(69-94)$ \\
\hline & & & Sept. 78 & 3 & 2.5 & $(2.2-2.8)$ & 93 & $(83-99)$ \\
\hline \multirow[t]{3}{*}{ Toquer } & Paraffin wax $\left(1.5 \mathrm{~kg} / \mathrm{m}^{2}\right)$ & July 77 & Aug. 77 & 3 & 1.3 & $(1.2-1.4)$ & 95 & $(92-98)$ \\
\hline & & & May 78 & 3 & 1.5 & $(1.2-1.9$ & 89 & $(86-92)$ \\
\hline & & & Sept. 78 & 3 & 1.8 & $(1.5-2.1)$ & 91 & $(74-100)$ \\
\hline \multirow[t]{3}{*}{ Gubler } & Paraffin wax $\left(1.5 \mathrm{~kg} / \mathrm{m}^{2}\right)$ & July 77 & Aug. 77 & 2 & 1.5 & $(1.4-1.5)$ & 59 & $(28-29)$ \\
\hline & & & May 78 & 2 & 3.2 & $(2.6-3.7)$ & 48 & $(36-59)$ \\
\hline & & & Sept. 78 & 3 & 6.2 & $(5.2-7.7)$ & 48 & $(37-56)$ \\
\hline Corner & Paraffin wax $\left(0.9 \mathrm{~kg} / \mathrm{m}^{2}\right)$ & Aug. 77 & May 78 & 4 & 1.7 & $(1.4-2.3)$ & 99 & $(96-100)$ \\
\hline Graham & Paraffin wax $\left(0.9 \mathrm{~kg} / \mathrm{m}^{2}\right)$ & Aug. 76 & May 78 & 3 & 1.2 & $(1.2-1.2)$ & 100 & $(100-100)$ \\
\hline
\end{tabular}

1 Prior to 1975.

advantage in maintaining high soil temperature which aided in remelting the wax and resealing the catchment surface.

\section{Summary and Conclusions}

The performance of a water harvesting system depended upon the effectiveness of the catchment apron treatment to inhibit infiltration. Water yield estimates of operational water-harvesting catchments are usually based on the average runoff obtained from small instrumented similarly treated plots. A small portable sprinkler was developed to estimate the runoff efficiency of operational water harvesting catchments. The sprinkler method, which evaluates 1-meter-square portions of the catchment, was validated by comparing the results with actual precipitation-runoff measurements from various catchment treatments at the Granite Reef Test Site. This sprinkler method permitted the evaluation of the performance of operational water-harvesting catchments, without the labor and expense of standard runoff instrumentation.

The sprinkler was used to estimate the runoff efficiency from various type treatments on 14 operational catchments. The results indicated that membrane treatments, like asphalt fiberglass or butyl, yield 90 to $100 \%$ precipitation runoff. A gravel-covered polyethylene treatment required a high threshold rainfall quantity to overcome the water retention within the gravel layer. Small holes in the plastic sheeting contributed to the low runoff efficiency.

The sprinkler results from the wax-treated catchments showed that this treatment can be effective treatment for water harvesting catchments. One wax catchment had a very poor runoff efficiency. Further studies are needed to explain why the wax treatment was not effective on this catchment.

\section{Literature Cited}

Cooley, K.R., G.W. Frasier, and K.R. Drew. 1978. Water harvesting: an aid to management. Proceedings, First International Rangeland Congress, Denver, Colorado, 14-18 Aug. 1978, p 292-294.

Fink, D.H., and G.W. Frasier. 1977. Evaluating weathering of water harvesting catchments from rainfall-runoff analysis. Soil Sci. Soc. Amer. J. 41:618-622.

Fraiser, G.W. 1975. Water harvesting: a source of livestock water. J. Range Manage. 28:429-434.

Myers, L.E., and G.W. Frasier. 1969. Creating hydrophobic soil for water harvesting. J. Irr. and Drain. ASCE, Vol. 95, No. IR1, Proc. Paper 6436. 